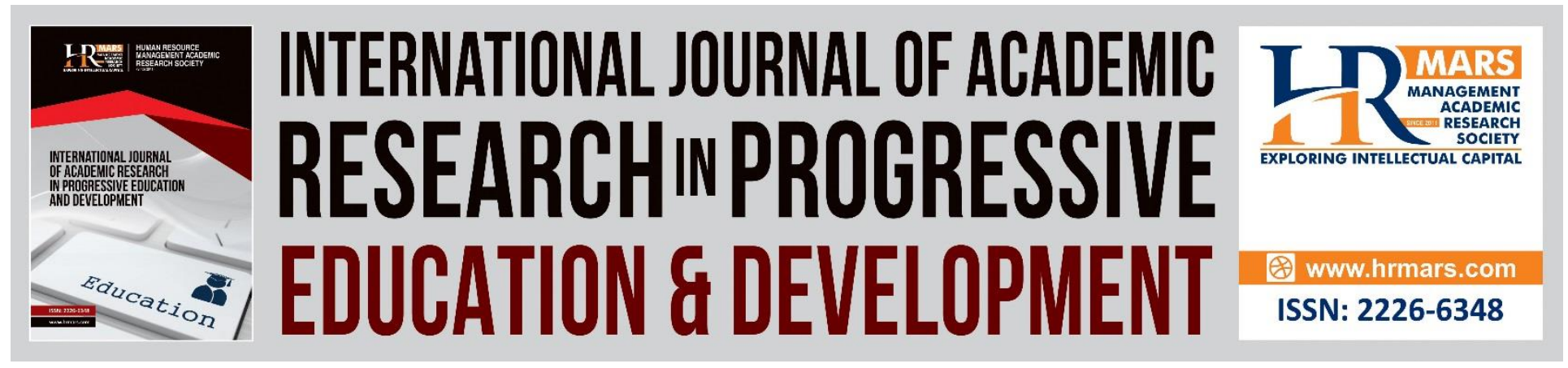

\title{
Reading Comprehension Problems in English Among Malaysian Primary Year 4 ESL Pupils
}

Pei Chia Chua, Nur Ainil Sulaiman

To Link this Article: http://dx.doi.org/10.6007/IJARPED/v10-i2/10101

DOI:10.6007/IJARPED/v10-i2/10101

Received: 06 April 2021, Revised: 12 May 2021, Accepted: 25 May 2021

Published Online: 18 June 2021

In-Text Citation: (Chua \& Sulaiman, 2021)

To Cite this Article: Chua, P. C., \& Sulaiman, N. A. (2021). Reading Comprehension Problems in English Among Malaysian Primary Year 4 ESL Pupils. International Journal of Academic Research in Progressive Education and Development, 10(2), 797-813.

Copyright: (C) 2021 The Author(s)

Published by Human Resource Management Academic Research Society (www.hrmars.com)

This article is published under the Creative Commons Attribution (CC BY 4.0) license. Anyone may reproduce, distribute, translate and create derivative works of this article (for both commercial and non-commercial purposes), subject to full attribution to the original publication and authors. The full terms of this license may be seen

at: http://creativecommons.org/licences/by/4.0/legalcode

Vol. 10 (2) 2021, Pg. 797 - 813

http://hrmars.com/index.php/pages/detail/IJARPED

JOURNAL HOMEPAGE

Full Terms \& Conditions of access and use can be found at http://hrmars.com/index.php/pages/detail/publication-ethics 


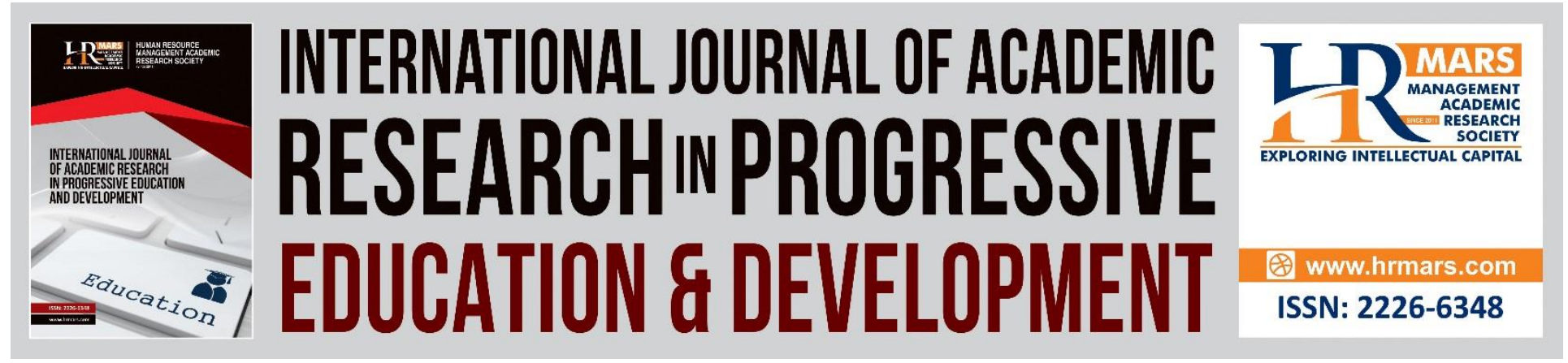

\title{
Reading Comprehension Problems in English Among Malaysian Primary Year 4 ESL Pupils
}

\author{
Pei Chia Chua, Nur Ainil Sulaiman \\ Universiti Kebangsaan Malaysia \\ Email: peichia11@gmail.com, nurainil@ukm.edu.my
}

\begin{abstract}
The preliminary study was motivated by concern over the problems that affect reading comprehension among Year 4 ESL pupils in a government Chinese vernacular primary school in Johor, Malaysia. It was aimed at identifying Malaysian primary Year 4 ESL pupils' reading comprehension problems in narrative text. Data were collected through the use of 15-item questionnaire with a 5-point Likert scale which involved 80 pupils that were randomly selected as sample for the study. Percentages were used to analyze the data collected. The findings revealed that the problems studied affected pupils' reading comprehension. The most significant problem in reading comprehension among Year 4 ESL pupils was the motivation. Pupils lack the desire in reading English texts and were uninterested in the topics. The second and third problems were perceived to be background knowledge and learners' background knowledge respectively. The respondents perceived the reading process as the least problematic. The implications of the study are teachers should be more aware of the reading problems faced by the pupils and use more interactive teaching strategies.

Keywords: Reading Comprehension Problems, Reading Skills, Second Language Acquisition, ESL Pupils
\end{abstract}

\section{Introduction}

Reading is a fundamental skill that is entwined with other abilities such as listening, speaking and writing. Pupils are expected to comprehend reading material to achieve the best results possible in teaching and learning. According to Bano, Jabeen and Quitoshi (2018), reading is a skill that teaches pupils how to extract ideas from text and create an understanding of that idea. This implies that reading serves as a process for pupils to acquire knowledge and information throughout the learning process.

A pupil who enjoys reading and devotes significant time to reading activities also possesses the skill to write. Pupils can increase their writing and vocabulary ability through reading (Yunus, Mohamad \& Waelateh, 2016). On the other hand, a pupil with limited reading ability will struggle during the learning process. Additionally, pupils will experience 
embarrassment as they adjust to their new school environment. On the other hand, an excellent teacher must be more adept at mastering vocabulary and grammar comprehension. Reading instruction aims to develop pupils' knowledge and ability to comprehend the contents of reading texts. This includes the ability to read a variety of English texts, the ability to adapt reading strategies to the reading purpose, such as skimming and scanning, and the skill to have a critical view on the texts contents (Halamish \& Elbaz, 2019).

Reading well entails comprehending the message a writer is attempting to convey through the writing. The learner must have content competence and knowledge in order to read. Alexander (2018) stated that certain pupils construct meaning from the reading text with their experience and prior knowledge. They connect the text's ideas to what they already know in order to gain comprehension. The majority of pupils can understand the contents after they read each and every word and spend an inordinate amount of time repeating the text's difficult terms.

Reading comprehension is the capacity to comprehend idea contained in a text and to appropriately guess the text's meaning (Mansor, 2017). That is, reading comprehension is the ability to read, process, and comprehend text. The skill of an individual to undersrtand text is affected by their inherent abilities and characteristics that is the capacity to make inferences. Additionally, reading comprehension can enhance writing and vocabulary ability. According to Iman (2016), there are five components of reading comprehension that pupils should know in order to comprehend a reading text effectively. These components include determining the main idea, locating specific information, drawing inferences, finding references, and understanding the word meanings or elaborated idea. These facets are the obstacles that pupils face when attempting to comprehend the text.

Reading comprehension in Malaysian primary schools aims to improve pupils' ability to comprehend what they read. Each school implements a syllabus that is tailored to the unique requirement of its pupils. The nature of syllabus is more positive that may help to motivate pupils, enhance their knowledge and abilities, and foster the development of positive values or even attitudes. Nowadays, the majority of schools implement the CEFR-aligned curriculum as the basis for their English as a second language curriculum (ESL). The CEFR is a critical component of Malaysia's Education Blueprint, which aims to bring the country's educational level up to international standards within the next decade.

According to the CEFR framework, pupils are required to understand social functions, language features and text structure when reading narrative texts, both oral and written. However, the pupils have not met the syllabus expectations in reality and have a limited ability to comprehend what they read. While authentic texts such as English magazines, newspapers, and articles play an important role in helping pupils improve their reading ability and knowledge of current events, they are not always easy for pupils to read and comprehend.

However, it is critical to understand the problems associated with reading comprehension. The difficulties that pupils face vary according to school. The majority of pupils struggle to read narrative texts taken from newspapers, articles, textbooks, and magazines. As a result, the preliminary study sought to identify the primary reading comprehension problems encountered by Malaysian primary ESL pupils. 
In light of the problems, the research question for this study was:

1. What are the primary reading comprehension problems encountered by Malaysian primary ESL pupils?

\section{Literature Review}

\section{Common European Framework of Reference (CEFR)}

According to Zalizan and Rohani (2015), one in every six children (15\%) in Malaysia has early difficulties with reading comprehension. The Council of Europe's adoption of the CEFR in 2001 signalled the start of a new era for language teaching and testing worldwide. Due to its uniformity and openness in language testing, it is viewed as a possible indicator that could be integrated into a variety of educational systems worldwide (Mara \& Michael, 2018). It provides stakeholders with a reference guide for not only developing language syllabus and curriculum, but also for planning course books and assessing learning outcomes. According to Azli and Aini (2020), the CEFR is a system structured to serve as a global reference for an individual's English-language competencies and proficiencies. Additionally, they stated that the CEFR establishes level-specific objectives with quantifiable outcomes. Sallehhudin and Farehah (2017) define it as a generally accepted standard of performance and skill in language assessment and education, and it is implemented in language programmes and tests globally.

Language learners' levels are classified into six categories in this reference tool: $\mathrm{A} 1$ and $A 2$ as the basic users, B1 and B2 as the independent users as well as C1 and C2 as the conversational users or proficient users. Each level is thoroughly described in the CEFR document. Each level is described in detail, including the competencies necessary for effective communication, the skills and knowledge necessary for ESL acquisition and proficiency, and the situations and contexts in which communication occurs (Council of Europe, 2001). Based on the framework, reading is not only a knowledge collection or comprehension process, as artistic and creative application of language are significant independent and educational, and aesthetic activities can be receptive mediating, interactive, productive and oral or written.

\section{Teaching of Reading in Malaysian Context}

English is taught and exposed to children in Malaysia's educational system at the early age of 5 to 6 years old in preschool, and is continued as a mandatory curriculum throughout primary and secondary school. The educational system has emphasised the importance of English language learning to achieve the evolving demands of Information, Science and Technology (ICT) and the Fourth Industrial Revolution that require Malaysian pupils to be proficient language users to compete in the international world. This is reflected in the Malaysian Education Reformation's Shift 2 of the Malaysian Education Blueprint (2013-2025), which emphasises the importance of pupils being at least bilingual in Malay and English. English language as a mandatory course is intended to pupils to acquire the language throughout their education. English language acquisition entails the development of listening and speaking abilities, as well as components of reading, writing, and grammar. In the Malaysian primary school classroom, these skills are taught using a modular approach, with each skill receiving its own lesson. Additionally, the NILAM programme is used to improve pupils' reading abilities and inculcate a love of reading. Thus, 
pupils are required to be able to read in both English and Malay by the end of the six-year primary schooling.

Reading ability does not only require pupils to correctly pronounce the voabulary, but to understand the semantic structures of the English language and the dictionary definitions. Chang et al. (2018) stated that reading comprehension is an active mental activity that requires interaction between the reader and the text. Phantharakphong and Pothita (2014) elaborated that pupils have problems with written text comprehension because they have not yet mastered reading comprehension. Reading comprehension is difficult for young learners in primary school as a result of the language's complexity, which includes vocabulary, grammar, and lexical form although reading skills are inculcated in their early education. According to New Straits Times (2016), the Ministry of Education (MoE) reported in Kamarundzaman (2014) that there were 162,000 illiterate primary and secondary school Malaysian students. Primary schools accounted for 120,000 of the 162,000 illiterate learners. Additionally, Fong (2020) discovered that Malaysian learners' overall English literacy rate was only 27.2\%. Additionally, Hayes (2014) discovered that policy plans to reduce the beginning age for ESL language instruction in primary schools failed. These statistics are concerning for our educational system, as despite the introduction of English as a mandatory subject in Year 1, pupils continue to struggle with reading proficiency. According to Mansor (2017), governments, educators, and other stakeholders in the education sector all have an interest in inculcating reading habits because reading is a necessary skill for the learners.

As a result, since the early 1960s, reading comprehension difficulties among Mlaysian primary pupils have been a focus of attention (Vellutino et al., 2004). Language comprehension does not only need verbal comprehension, but also the skill to actively engage with the content in order to create a cognitive representation (Rashid, 2012). Wolf and Bowers (1999) linked low reading comprehension ability to specific components of reading disabilities, including selective rapid automated naming (RAN) deficits, selective phonological deficits and combined deficits. Reduced reading time, combined with a limited vocabulary and general knowledge lead to reading comprehension problems (Yunus, Mohamad, \& Waelateh, 2016). Several studies have been conducted on reading comprehension for ESL pupils (Zare \& Nooreen, 2011). However, it is critical to identify the causes that lead to inadequate primary reading comprehension to apply the recommended approaches efficiently (Iqbal et al., 2015).

\section{Reading Comprehension}

Text comprehension entails extracting information from it. Reading comprehension requires pupils to demonstrate their understanding of a text by responding to text-related questions. Due to their low reading frequency, this activity may be challenging for pupils. According to Sidhu, Kaur, and Lee (2018), the majority of ESL pupils lacked a strong reading habit despite formal schooling in English. It could be a result of the teacher or parents providing less motivation at home. Reading habit is a type of repeating reading practice, which means that the activity must be performed on a consistent basis. To motivate pupils to read, reading comprehension requires familiarity with the subject. Individuals are typically motivated to read when they believe the material will be beneficial to them. This is why the classroom topic should be determined by what the pupils believe they require. Reading comprehension, in the context of classroom activities, 
entails several types of questions. Several of them involve identifying central concepts and vocabulary knowledge associated with synonyms and antonyms, as well as responding to detailed questions.

Pupils may run into a variety of reading comprehension difficulties while reading a text. Several factors include the learner's word knowledge, content knowledge, motivation, reading strategies, and the reading process (Marashi \& Rahmati, 2017). Before pupils can read in a second language, it is assumed that they should gain language knowledge beforehand. As pupils cannot comprehend a sentence without first associating the word with its meaning, a passage containing a large number of unfamiliar words creates comprehension difficulties. The finding corroborates Alderson's (2000) statement that many pupils are unable to read appropriately in a second language, as a result of which they are unable to comprehend what they read and also read slowly. It impairs pupils' efficiency and effectiveness in the second language, preventing them from successfully transferring them. The reading comprehension problem is due to the failure in syntactic and semantic analysis, single-word analysis and weak understanding in referring meaning from text, combining information, and evaluating their own comprehension (Oakhill, 1993).

Pupils' content knowledge which includes their cultural background, is defined as prior knowledge. Pupils make use of it to generate another idea into their existing knowledge. Additionally, if pupils do not fully comprehend other relevant cultures, an unfamiliar cultural context and gaps between content knowledge of culture and vocabulary knowledge result in reading incomprehension. Moreover, reading narrative texts becomes difficult due to lack of text type comprehension and organisation. If pupils are unaware of the genre of the text, such as fairy tales, newspapers or business letters, they will struggle to comprehend the content. Pupils who are familiar with the types of reading materials can comprehend it easily.

Pupils' motivation can influence the outcome of a reading assignment. Studies of second language pupils have revealed that pupils have low motivation to read or improve their reading abilities and it serves as an impediment to reading comprehension. At the same time, it has long been recognised that when pupils are truly engaged in reading materials and it can significantly outweigh other factors in reading. Indeed, reading motivation or content interest may be the most significant cause in reading comprehension problems. Positive motivation has been shown to be an important factor in reading development, as it directly encourages comprehension through increased level of extended reading. If pupils lack the motivation to read, reading strategies and content knowledge will be inactive and ineffective. As a result, reading suffers when the reader is dissatisfied with the material.

Another cause that contributes to reading comprehension problems is a lack of reading strategies. Pupils who have gained reading strategies or skills are capable of efficiently processing text. Reading serves as an active activity that requires the pupils to make effective application of strategies in order to comprehend knowledge. Additionally, reading strategies describe the ways pupils think or understand a text and generate reading information if reading comprehension becomes challenging. Reading methods, behaviours, problem-solving skills, and study skills are all examples of strategies that increase the effectiveness and efficiency of learning. Without or 
improper use of reading strategies, pupils will be unable to overcome reading difficulties and achieve comprehension.

Reading is a two-way process between the text and the reader. When pupils read, a variety of processes occur in their minds. While pupils are reading the printed text, they decode, determine and connect the meaning to one another thing they are in mind, guess and anticipate the aim for which they will read. As previously stated, numerous events happen when a learner reads and the process appears to be variable, dynamic and unique when they read the same text at a different aim or time. Understanding the process of nature reading is critical. However, this is exceedingly difficult to accomplish because reading is typically internal, silent and private. Reading is a psycholinguistic activity in which pupils do not make use of all the ideas. Consequently, they need not understand every single word in order to know the text. While embedded clauses in long sentences will be more difficult to comprehend, research on ESL acquisition indicates that pupils can comprehend texts that exceed their syntactic ability. They can overlook grammatical errors and derive definitions from other sources, such as context or vocabulary clues, and still comprehend a text. This is the section in which pupils must choose the most effective language cues in order to deduce the writer's message. Additionally, reading is a difficult process that requires reconstructing the writer's meaning.

\section{Methodology \\ Research Design}

The preliminary study used a survey design, a quantitative approach, to identify the main reading comprehension problems experienced by Malaysian primary ESL pupils. Additionally, survey research is a fairly reliable method of inquiry. This is because surveys are standardised in the sense that participants are asked the same questions, phrased exactly the same way.

\section{Populations and Samples}

In this preliminary study, respondents were chosen using a convenient random sampling technique. They were eighty ESL students from a government primary Chinese vernacular school in Pasir Gudang, Johor. Year 4 pupils were chosen because they had developed reading skills in a CEFR-aligned curriculum classroom from Year 1 to 3 . As a result, they have a wealth of background knowledge and a working knowledge of reading comprehension strategies. Two classes of pupils were present. The sample size was sufficient to elicit information about the ESL pupils' reading comprehension problems.

\section{Research Instruments}

The research design for this study was a quantitative survey. Eighty ESL pupils from Malaysian primary schools were sent an online Google Form questionnaire (Refer to Appendix A). The questionnaire was a rating scale questionnaire, and the research collected data from participants using a Likert scale. The Likert scale was a psychometric response scale that was primarily used in questionnaires to ascertain respondents' preferences or level of agreement with a statement or set of statements. Likert scales are a non-comparative scaling technique that is onedimensional in nature as it measures only a single trait. With a given statement, respondents were asked to indicate their level of agreement on an ordinal scale. These questionnaires contain 
Vol. 10, No. 2, 2021, E-ISSN: 2226-6348 @ 2021 HRMARS

five items that assess pupils' abilities. It required subjects to rate their agreement on a five-point scale that included totally disagree, disagree, neutral, agree, and totally agree. Each item was scored in such a way that responses indicating a predefined "strong" pupil problem received 5 points, while those at the opposite end of the scale received 1 point. Pupils were given a questionnaire to complete in order to respond to all of the statements and questions. The indicators of pupils' reading comprehension problems are stated in Table 3.1.

Table 3.1 Indicators of pupils' reading comprehension problems

\begin{tabular}{|c|c|c|c|}
\hline Difficulties & Sub Indicators & $\begin{array}{c}\text { Item } \\
\text { Numbers }\end{array}$ & Total \\
\hline $\begin{array}{c}\text { Word } \\
\text { knowledge }\end{array}$ & $\begin{array}{l}\text { 1. Inadequate language knowledge } \\
\text { regarding narrative text. } \\
\text { a. Pupils lack knowledge of the generic } \\
\text { structure of narrative texts. } \\
\text { b. Pupils lack knowledge of grammar. }\end{array}$ & 1,2 & 2 \\
\hline $\begin{array}{c}\text { Content } \\
\text { knowledge }\end{array}$ & $\begin{array}{l}\text { 1. Pupils lack of background } \\
\text { knowledge. } \\
\text { a. Unfamiliar cultural context. } \\
\text { b. Lack of vocabulary knowledge. } \\
\text { c. Unfamiliar with the text type. }\end{array}$ & $3,4,5,6$ & 3 \\
\hline Motivation & $\begin{array}{l}\text { 1. Lack of motivation to read. } \\
\text { a. Lack of desire to read English texts. } \\
\text { b. Lack of motivation to read English } \\
\text { texts. } \\
\text { c. Lack of interest in the topic. }\end{array}$ & $7,8,9$ & 3 \\
\hline $\begin{array}{c}\text { Reading } \\
\text { strategies }\end{array}$ & $\begin{array}{l}\text { 1. Deficiency in the development of } \\
\text { effective and efficient strategies. } \\
\text { a. Boring reading instruction. } \\
\text { b. Read every single word in order to } \\
\text { comprehend the text. }\end{array}$ & $10,11,12$ & 3 \\
\hline Reading process & $\begin{array}{l}\text { 1. There is no interaction between the } \\
\text { reader and the text. } \\
\text { a. Pupil is unable to predict what will } \\
\text { happen next in the text. } \\
\text { b. Pupil misses the attention of the long } \\
\text { sentences in the text. } \\
\text { c. Pupil does not make full use of the } \\
\text { ideas on the page. }\end{array}$ & $13,14,15$ & 3 \\
\hline
\end{tabular}

\section{Data Collection}

To validate the data that is necessary to address the research problems, the researcher sought permission from the subjects to conduct the research. The questionnaire was administered online rather than on paper, allowing respondents greater flexibility in terms of response time 
Vol. 10, No. 2, 2021, E-ISSN: 2226-6348 @ 2021 HRMARS

and location. The researcher collected data, analysed it, and came to a summary as a finding of the research.

\section{Data Analysis}

The percentage and the pupils' responses were calculated through the total of each item, which was then multiplied by a hundred percent. The result was divided by the total number of pupils. As the researcher used the Likert scale to assess pupils' difficulties, the researcher calculated the percentage result using the Likert scale. The Likert scale for reading comprehension problems is shown in Table 3.2.

Table 3.2 Likert scale for pupils' reading comprehension problems

\begin{tabular}{cl}
\hline Strongly agree & 1 \\
\hline Agree & 2 \\
\hline Neutral & 3 \\
\hline Disagree & 4 \\
\hline Strongly disagree & 5 \\
\hline
\end{tabular}

The score of pupils' responses (PRS) was calculated with every single question by using formula as follow:

Information:

$$
\%=\frac{\Sigma P R S}{P R S \text { maksimum }} \times 100 \%
$$

$\sum$ PRS : the total of pupils' response score was calculated with the formula $S R S=\sum R x$ the best score choice (5)

The percentage result could be measured by using Likert scale as shown in Table 3.2.

Table 3.3 Criteria of Pupils' Response

\begin{tabular}{cc}
\hline Percentage & Criterion \\
\hline $0 \%-20 \%$ & Very Weak \\
\hline $21 \%-40 \%$ & Weak \\
\hline $41 \%-60 \%$ & Average \\
\hline $61 \%-80 \%$ & Strong \\
\hline $81 \%-100 \%$ & Very Strong \\
\hline
\end{tabular}

\section{Validity and Reliability}

The most critical characteristic to measure and process instrument is validity. It was related to the suitability of test score interpretations. In this study, validity is further subdivided into construct validity. The extent to which a data collection instrument generates scores that can be applied to infer about a construct is referred to as construct validity. This is a term that refers to the construct validity of a questionnaire to determine the consistency of the questionnaire with the theory.

The term "reliability" is the consistency of the obtained scores across multiple administrations of an instrument and multiple sets of items. Reliability of the questionnaire is 
Vol. 10, No. 2, 2021, E-ISSN: $2226-6348$ @ 2021 HRMARS

necessary for data collection in order to determine the questionnaire's reliability. The questionnaire assessed the pupils' reading comprehension problems in narrative texts using the Likert scale. Cronbach's Alpha was used to determine the reliability, which was calculated using the computer programme SPSS.

\section{Findings and Discussion}

Completed data was acquired from the questionnaire. The data was analyzed systematically and accurately to gain the objective of the research and draw conclusion about the objective of the study.

\section{Word Knowledge}

The first section of the questionnaire was aimed at word knowledge in reading comprehension among the pupils to take part in the survey. Table 4.1 shows the percentage of pupils' response score of the first section that consisted of two items. The first statement was 'I can't understand what I read as I don't know about the generic structure on narrative text'. The second statement was 'I have a hard time to master grammar in a text'.

Table 4.1 Percentage of the Statement 1-2

\begin{tabular}{|c|c|c|c|c|c|c|c|}
\hline \multirow[b]{2}{*}{ No. } & \multicolumn{5}{|c|}{ Percentage of answer } & \multirow{2}{*}{$\begin{array}{l}\text { Percentage } \\
\text { of pupils' } \\
\text { response } \\
\text { score }\end{array}$} & \multirow[b]{2}{*}{ Criterion } \\
\hline & $\begin{array}{l}\text { Strongly } \\
\text { Disagree }\end{array}$ & Disagree & Neutral & Agree & $\begin{array}{c}\text { Strongly } \\
\text { Agree }\end{array}$ & & \\
\hline 1. & $8(10 \%)$ & $26(32.5 \%)$ & $17(21.25 \%)$ & $21(26.25 \%)$ & $8(10 \%)$ & $58.75 \%$ & Average \\
\hline 2. & $4(5 \%)$ & $20(25 \%)$ & $17(21.25 \%)$ & $24(30 \%)$ & $15(18.75 \%)$ & $66.5 \%$ & Strong \\
\hline
\end{tabular}

Based on Table 4.1, the percentage of pupils' response score in Statement 1 had average criterion with $58.75 \%$. Most of the pupils disagreed with the lack of knowledge in reading comprehension by $32.5 \%$, followed by agree level (26.25\%), neutral level ( $21.25 \%)$, both strongly disagree and strongly agree level at $10 \%$. It shows that most of the pupils disagreed with the lack of word knowledge about narrative text in reading comprehension.

On the other hand, the data in Table 4.1 showed that pupils agreed with Statement 2 and had strong percentage criterion with $66.5 \%$. Most of the pupils agreed with the lack of knowledge in reading comprehension by $30 \%$, followed by disagree level (25\%), neutral level $(21.25 \%)$, strongly disagree at $18.75 \%$ and strongly disagree level at $5 \%$. It means pupils had problem of grammar knowledge.

\section{Content Knowledge}

The second section of the questionnaire was aimed at learner's background knowledge in reading comprehension among the pupils to take part in the survey. Table 4.2 shows the percentage of pupils' response score of the second section that consisted of three items. The third statement 
Vol. 10, No. 2, 2021, E-ISSN: $2226-6348$ @ 2021 HRMARS

was 'I know most of the word associated with culture on the text, but I don't understand the whole section and the basic idea'. The fourth statement was 'I don't understand the meaning of English vocabulary that I learned'. The fifth statement was 'I can't memorize new English language vocabulary that is long and complicated'. The sixth statement is 'I don't understand the type of text I read'.

Table 4.2 Percentage of the Statement 3-6

\begin{tabular}{|c|c|c|c|c|c|c|c|}
\hline \multirow[b]{2}{*}{ No. } & \multicolumn{5}{|c|}{ Percentage of answer } & \multirow{2}{*}{$\begin{array}{l}\text { Percentage } \\
\text { of pupils' } \\
\text { response } \\
\text { score }\end{array}$} & \multirow[b]{2}{*}{ Criterion } \\
\hline & $\begin{array}{l}\text { Strongly } \\
\text { Disagree }\end{array}$ & Disagree & Neutral & Agree & $\begin{array}{c}\text { Strongly } \\
\text { Agree }\end{array}$ & & \\
\hline 3. & $6(7.5 \%)$ & $24(30 \%)$ & $11(13.75 \%)$ & $16(20 \%)$ & $23(28.75 \%)$ & $66.5 \%$ & Strong \\
\hline 4. & $10(12.5 \%)$ & $27(33.75 \%)$ & $6(7.5 \%)$ & $23(28.75 \%)$ & $14(17.5 \%)$ & $61 \%$ & Strong \\
\hline 5. & $23(28.75 \%)$ & $17(21.25 \%)$ & $8(10 \%)$ & $16(20 \%)$ & $16(20 \%)$ & $56.25 \%$ & Average \\
\hline 6. & $11(13.75 \%)$ & $11(13.75 \%)$ & $11(13.75 \%)$ & $32(40 \%)$ & $15(18.75 \%)$ & $67.25 \%$ & Strong \\
\hline
\end{tabular}

The data presented that $13.75 \%$ of pupils were neutral in unfamiliar cultural context, $20 \%$ of them had agreed with this problem and several of them were strongly agreed in the third statement by $28.75 \%$ that they knew most of the words related to the text culture, but they had problems to understand the basic idea in the whole section due to limited content knowledge. The opposite of it was $30 \%$ of pupils who disagreed with the statement and $7.5 \%$ of them strongly disagreed with it. The data indicated strong percentage criterion with $66.5 \%$.

Based on Table 4.2, pupils agreed with Statement 4 and had strong percentage criterion with $61 \%$. Most of the pupils disagreed with the lack of learner's background knowledge in reading comprehension by $33.75 \%$, followed by agree level $(28.75 \%)$, strongly agree level (17.5\%), strongly disagree level at $18.75 \%$ and strongly disagree level at $5 \%$. It means pupils had problems of grammar knbowledge.

The data also showed that the percentage of pupils' response score was at the average criterion of $56.25 \%$ which indicated that more than half of the pupils had difficulty to memorize new English language vocabulary that was long and complicated. There were $28.75 \%$ pupils strongly disagreed with the statement, followed by disagree level (21.25\%), both agree and strongly agree level at $20 \%$ and neutral at $10 \%$.

Based on the data, that percentage of pupils' response score of fifth statement was at the strong criterion by $67.25 \%$. Pupils who agreed that they did not really understand the types of text due to limited background knowledge were at its highest at $40 \%$, followed by those who strongly agreed (18.75\%). The data presented similar percentages of answer at $13.75 \%$ for pupils who strongly disagreed, disagreed and neutral with the statement. 
Vol. 10, No. 2, 2021, E-ISSN: 2226-6348 @ 2021 HRMARS

\section{Motivation}

The third section of the questionnaire was aimed at learner's motivation in reading comprehension among the pupils to take part in the survey. Table 4.3 shows the percentage of pupils' response score of the third section that consisted of three items. The seventh statement was 'I don't like reading books'. The eighth statement was 'I'm lazy to read when the text is too difficult, boring and not interesting'. The ninth statement was 'I face a lot of troubles when I am not interested in the text topic discussed'.

Table 4.3 Percentage of the Statement 7-9

\begin{tabular}{cccccccc}
\hline & \multicolumn{9}{c}{ Percentage of answer } & \multicolumn{3}{c}{$\begin{array}{c}\text { Percentage } \\
\text { of pupils' }\end{array}$} & Criterion \\
\cline { 2 - 8 } No. & $\begin{array}{c}\text { Strongly } \\
\text { Disagree }\end{array}$ & Disagree & Neutral & Agree & $\begin{array}{c}\text { Strongly } \\
\text { Agree } \\
\text { response } \\
\text { score }\end{array}$ & \\
\hline 7. & $13(16.25 \%)$ & $21(26.25 \%)$ & $7(8.75 \%)$ & $16(20 \%)$ & $23(28.75 \%)$ & $63.75 \%$ & Strong \\
\hline 8. & $14(17.5 \%)$ & $19(23.75 \%)$ & $9(11.25 \%)$ & $19(23.75 \%)$ & $19(23.75 \%)$ & $62.5 \%$ & Strong \\
\hline 9. & $17(21.25 \%)$ & $14(17.5 \%)$ & $8(10 \%)$ & $16(20 \%)$ & $25(31.25 \%)$ & $64.5 \%$ & Strong \\
\hline
\end{tabular}

Based on Table 4.3, the data presented that $8.75 \%$ of pupils were neutral in motivation in reading comprehension, $20 \%$ of them had agreed it and several of them were strongly agreed in the seventh statement by $28.75 \%$ that they did not like reading books. The opposite of it was $26.25 \%$ of pupils who disagreed with the statement and $16.25 \%$ of them strongly disagreed with it. The data indicated strong percentage criterion with $63.75 \%$.

Table 4.2 also showed that pupils agreed with the eighth statement and had strong percentage criterion with $62.5 \%$. There were equal percentage of answers among the pupils who were lazy to read when the text was too difficult, boring and not interesting at disagree, agree and strongly agree level by $23.75 \%$, followed by strongly disagree level (17.5\%) and neutral level at $11.25 \%$.

The data also showed that the percentage of pupils' response score for ninth statement was at the strong criterion of $64.5 \%$ which indicated that more than half of the pupils faced a lot of troubles when they were not interested in the text topic discussed. There were $31.25 \%$ of pupils strongly strongly agreed with the statement, followed by disagree level $(21.25 \%)$, agree level (20\%) disagree level at $17.5 \%$ and neutral at $10 \%$.

\section{Reading Strategies}

The fourth section of the questionnaire was aimed at learner's lack of reading strategies in reading comprehension among the pupils to take part in the survey. Table 4.4 shows the percentage of pupils' response score of the fourth section that consisted of three items. The tenth statement was 'I read aloud to help me remember well'. The eleventh statement was 'I 
INTERNATIONAL JOURNAL OF ACADEMIC RESEARCH IN PROGRESSIVE EDUCATION AND

DEVELOPMENT

Vol. 10, No. 2, 2021, E-ISSN: 2226-6348 @ 2021 HRMARS

look for the meaning of vocabulary that I am not familiar in the dictionary'. The twelfth statement was 'I read every word in the text to understand the contents of the text'.

Table 4.4 Percentage of Statement 10-12

\begin{tabular}{|c|c|c|c|c|c|c|c|}
\hline \multirow[b]{2}{*}{ No. } & \multicolumn{5}{|c|}{ Percentage of answer } & \multirow{2}{*}{$\begin{array}{l}\text { Percentage } \\
\text { of pupils' } \\
\text { response } \\
\text { score }\end{array}$} & \multirow[b]{2}{*}{ Criterion } \\
\hline & $\begin{array}{l}\text { Strongly } \\
\text { Disagree }\end{array}$ & Disagree & Neutral & Agree & $\begin{array}{c}\text { Strongly } \\
\text { Agree }\end{array}$ & & \\
\hline 10. & $10(12.5 \%)$ & $14(17.5 \%)$ & $18(22.5 \%)$ & $16(20 \%)$ & $22(27.5 \%)$ & $66.5 \%$ & Strong \\
\hline 11. & $11(13.75 \%)$ & $26(32.5 \%)$ & $15(18.75 \%)$ & $7(8.75 \%)$ & $21(26.25 \%)$ & $60.25 \%$ & Strong \\
\hline 12. & $17(21.25 \%)$ & $17(21.25 \%)$ & $17(21.25 \%)$ & $15(18.75 \%)$ & $14(17.5 \%)$ & $58 \%$ & Average \\
\hline
\end{tabular}

Based on Table 4.4, the data presented that $22.5 \%$ of pupils were neutral in learner's reading strategies in reading comprehension, $20 \%$ of them had agreed it and several of them were strongly agreed in the tenth statement by $27.5 \%$ that they read aloud to help them remember well. The opposite of it was $17.5 \%$ of pupils who disagreed with the statement and $12.5 \%$ of them strongly disagreed with it. The data indicated strong percentage criterion with $66.5 \%$.

Table 4.4 also showed that pupils agreed with the eleventh statement and had strong percentage criterion with $60.25 \%$. There were $32.5 \%$ of pupils disagreed that they always looked for the meaning of unfamiliar vocabulary in the dictionary, followed by strongly agree level (26.25\%), neutral at $18.75 \%$, strongly disagree level at $13.75 \%$ and agree level at $8.75 \%$.

The data also showed that the percentage of pupils' response score for twelfth statement was at the average criterion of $58 \%$ which indicated that more than half of the pupils read every word in the text to understand the contents of the text. There were equal percentage of pupils who strongly disagreed, disagreed and neural with the statement at $21.25 \%$, followed by agree level (18.75\%), and strongly agree at $17.5 \%$.

\section{Reading Process}

The fifth section of the questionnaire was aimed at learner's reading process in reading comprehension among the pupils to take part in the survey. Table 4.5 shows the percentage of pupils' response score of the fifth section that consisted of three items. The thirteenth statement was 'When reading, I can't predict next sentence'. The fourteenth statement was 'I struggle to concentrate on reading a long and boring text until the end'. The fifteenth statement was 'I don't understand information for each section, so I don't understand the message delivered by the author'. 
INTERNATIONAL JOURNAL OF ACADEMIC RESEARCH IN PROGRESSIVE EDUCATION AND

DEVELOPMENT

Vol. 10, No. 2, 2021, E-ISSN: 2226-6348 @ 2021 HRMARS

Table 4.5 Percentage of Statement 13-15

Percentage of answer

\begin{tabular}{cccccccc}
\hline & \multicolumn{9}{c}{ Percentage of answer } & \multicolumn{3}{c}{ Percentage } \\
\cline { 2 - 8 } No. & $\begin{array}{c}\text { Strongly } \\
\text { Disagree }\end{array}$ & Disagree & Neutral & Agree & $\begin{array}{c}\text { Strongly } \\
\text { Agree } \\
\text { response } \\
\text { score }\end{array}$ & Criterion \\
\hline 13. & $15(18.75 \%)$ & $17(21.25 \%)$ & $14(17.5 \%)$ & $15(18.75 \%)$ & $19(23.75 \%)$ & $61.5 \%$ & Strong \\
\hline 14. & $9(11.25 \%)$ & $19(23.75 \%)$ & $26(32.5 \%)$ & $12(15 \%)$ & $14(17.5 \%)$ & $60.75 \%$ & Strong \\
\hline 15. & $10(12.5 \%)$ & $24(30 \%)$ & $28(35 \%)$ & $7(8.75 \%)$ & $11(13.75 \%)$ & $56.25 \%$ & Average \\
\hline
\end{tabular}

Based on Table 4.5, the data presented that $17.5 \%$ of pupils were neutral in learner's reading process in reading comprehension, $18.75 \%$ of them had agreed it and several of them were strongly agreed in the thirteenth statement by $23.75 \%$ that they could not predict next sentence when reading. The opposite of it was $21.25 \%$ of pupils who disagreed with the statement and $18.75 \%$ of them strongly disagreed with it. The data indicated strong percentage criterion with $61.5 \%$.

Table 4.5 also showed that pupils agreed with the fourteenth statement and had strong percentage criterion with $60.75 \%$. There were $32.5 \%$ of pupils being neutral that they struggled to concentrate on reading a long and boring text until the end, followed by disagree level $(23.75 \%)$, strongly agree at $17.5 \%$, agree level at $15 \%$ and strongly disagree level at $11.25 \%$.

The data also showed that the percentage of pupils' response score for fifteenth statement was at the average criterion of $56.25 \%$ which indicated that more than half of the pupils did not understand information for each section, so they did not understand the message delivered by the author. There were $35 \%$ of pupils who are neutral to the statement, followed by disagree level (30\%), strongly agree at $13.75 \%$, strongly disagree level at $12.5 \%$ and agree level at $8.75 \%$. After analyzing fifteen items, the researcher found the pupils difficulties in reading comprehension.

There were five criteria for assessing pupils' reading comprehension difficulties. Table 4.6 summarises the findings. According to Table 4.6, 27\% of respondents favoured the "Average" criterion, while $73 \%$ favoured the "Strong" criterion. This indicates that the pupils struggled with reading comprehension due to a lack of content knowledge, content knowledge of the learner, motivation, reading strategies, and the reading process itself. Each component's results contained a $27 \%$ average, indicating that the pupils were neutral, and a $73 \%$ strong, indicating that the pupils encountered difficulties.

Table 4.6 Results of Reading Comprehension Problem Percentages

\begin{tabular}{cc}
\hline Results & Percentages \\
\hline Strongly & $\frac{11}{15} \times 100 \%=73 \%$ \\
\hline Average & $\frac{4}{15} \times 100 \%=27 \%$ \\
\hline
\end{tabular}


The study examined pupils' perceptions of the factors that contributed to their reading comprehension difficulties. Additionally, the study examined the differences in the reading comprehension difficulties perceived by all pupils. The difficulties associated with reading comprehension were classified into five major categories:

1. Word knowledge

2. Content knowledge

3. Motivation

4. Reading strategies

5. Reading process

The average result showed how pupils perceived reading comprehension problems as a whole. The pupils were unsure whether they encountered problems while reading in any of the five categories. However, three items were perceived as posing significant reading comprehension difficulties. To begin, respondents unanimously agreed that motivation was the primary barrier to reading comprehension. Alderson (2019) asserts that a pupil's motivation can influence the outcome of a reading assignment. Studies of low-achieving ESL pupils have revealed that low-achieving pupils were lack of motivation to read or improve their reading abilities. Consequently, low motivation becomes an impediment to reading comprehension. Additionally, pupils identified the primary causes of low performance in class, which included a dearth of visually appealing textbooks, cartoons and novels, as well as English materials that can pique pupils' interest in self-directed learning. In other words, the teacher can encourage pupils to read by choosing texts that are relevant to their interests. Second, pupils encountered an issue when reading a passage; they tended to connect its content to their own prior knowledge about the subject, which was occasionally inconsistent with what the author intended in the passage.

Despite pupils indicated that they were unsure whether they had the listed problems, the average indicated that the higher the number, the more pupils were aware of the reading problems. The pupils perceived the reading process as the least problematic. Pupils are capable of comprehending texts that exceed their syntactic ability. They can overlook grammatical errors and derive definitions from other sources such as context or vocabulary clues and still comprehend a text. Pupils must determine the writer's message by selecting the most effective language cues. Reading comprehension is a multifaceted activity that requires a range of linguistic and mental abilities. Therefore, deficiencies in any mental ability critical to the reading comprehension process may result in reading comprehension performance deficits. Perfetti and Stafura (2014) offered a comprehensive framework for comprehending the activities and abilities involved in reading comprehension; problems in comprehension can be caused by a variety of factors other than decoding, including sensitivity differences to story structure, comprehension monitoring, inference making, syntactic processing, verbal working memory, and oral language skills (Snowling \& Hulme, 2012). In general, the findings corroborated previous research. 


\section{Conclusion, Implications and Recommendations}

Malaysian primary Year 4 pupils' reading comprehension problems are caused by a lack of word knowledge, content knowledge, motivation, reading strategies, and reading process. Considering the findings of the research, teachers must be able to observe their pupils' reading comprehension difficulties in order to assist them in resolving all of their problems. Teachers should explain to pupils that an unsuccessful reader is one who stops at each unfamiliar word and immediately looks it up in the dictionary in order to comprehend the context. They should be instructed to attempt to complete an article by reading continuously with as little hesitation as possible in order to build up their conscious confidence in the absence of a dictionary. Additionally, teachers should encourage pupils to employ 'schemata,' or guessing unfamiliar vocabulary based on context clues. The significance of materials should be considered when developing a syllabus. Further research on engaging in interactive processes that aid pupil comprehension and strategies to aid pupil motivation in reading comprehension can be conducted.

\section{References}

Alderson, J. C. (2000). Assesing Reading. Cambrige: Cambridge University Press.

Alexander, F. (2018). Understanding Vocabulary. https://www.scholastic.com/teachers/articles/teaching.../understandingvocabulary [18 May 2021]

Bano, J., Jabeen, Z., \& Quitoshi, S. (2018). Perceptions of teachers about the role of parents in developing reading habits of children to improve their academic performance in schools. Journal of Education and Educational Development, 5(1), 42-59.

Common European Framework of Reference for Languages: Learning, Teaching, Assessment. (no date). Strasbourg: Language Policy Unit. https://www.coe.int/lang-cefr [18 May 2021]

Fong, P. C. (2020). Literacy among the Secondary Students in Malaysia. International Journal of Social Science and Humanity, 2, 34-45.

Halamish, V., \& Elbaz, E. (2019). Children's reading comprehension and metacomprehension on screen versus on paper. Computers \& Education, 2(1), 145-157.

Iman, A. (2016). Vocabulary Teaching Techniques: A Review of Common Practices. International Journal of Research in English Education, 1(1), 26-32.

Iqbal, M., Noor, M., Muhabat, F., \& Kazemian, B. (2015). Factors Responsible for Poor English Reading Comprehension at Secondary Level. Communication and Linguistic Studies, 1, 16.

Kamarundzaman, N. S. (2014). Using Phonics System to Develop Pupils' Reading Proficiency. Skudai: Universiti teknologi Malaysia.

Mansor, N. (2017). Exploring perceptions on ESL students' reading habits. Journal of Business and Social Development, 5(2), 19-24.

Marashi, H., \& Rahmati, P. (2017). The effect of teaching reading strategies on EFL learner's reading. International Journal of Research in English Education, 2(2). 43-52.

María, B., \& Michael, B. (2018). The current influence of the CEFR in secondary education: teachers' perceptions. Language, Culture and Curriculum. 
Abd Aziz, M. S., \& Uri, N. F. M. (2017). CEFR in Malaysia: Current issues and challenges in the implementation of the framework. The 3rd International Conference on Language Testing and Assessment and the 5th British Council New Directions in Language Assessment Conference.

Lee, N. A. B. A., \& Kasim, A. A. B. M. (2020). Implementation of common European framework of reference for languages-aligned assessment in Malaysian secondary schools. International Journal of Psychosocial Rehabilitation, 24(1), 747-757.

Oakhill, J. (1993). Children's Difficulties in Reading Comprehension. Educational Psychology Review, 5(3).

Phantharakphong, P., \& Pothitha, S. (2014). Development of English Reading Comprehension by Using Concept Maps. Procedia-Social and Behavioural Sciences, 116, 497- 501.

Rashid, A. M. (2012). Teachers' Understanding and Practice towards Thematic Approach in Teaching Integrated Living Skills (ILS) in Malaysia. International Journal of Humanities and Social Science, 2, 472.

Sidhu, G. K., Kaur, S. \& Lee, J. C. (2018). CEFR-aligned school-based assessment in the Malaysian primary ESL classroom. Indonesian Journal of Applied Linguistics 8(2), 452-463.

Wolf, M., \& Bowers, P. G. (1999). The Double-Deficit Hypothesis for the Dyslexia. Journal of Educational Psychology, 91, 415-438.

Yunus, K., Mohamad, M., \& Waelateh, B. (2016). The breadth of receptive vocabulary knowledge among English major university students. Journal of Nusantara Studies, 1(1), 7-17.

Zare, P., \& Nooreen, N. (2011). The Relationship between Language Learning Strategy Use and Reading Comprehension Achievement among Iranian Undergraduate EFL Learners. World Applied Sciences Journal, 13, 1870-1877. 